\title{
THE DEVELOPMENT OF BIOCHEMICAL RESEARCH TO IMPROVE THE PHYSIOLOGY OF CROP NUTRITION IN UKRAINE IN THE SECOND HALF OF THE $20^{\text {th }}$ CENTURY
}

\author{
Nataliia Kovalenko $^{1 *}$, Iryna Borodai ${ }^{1}$, Nataliia Shchebetiuk ${ }^{1}$ \\ ${ }^{1 *}$ Institute of History of Agrarian Science, Education and Technique of NSAL NAAS, Ukraine; \\ "Corresponding Author Nataliia Kovalenko, e-mail: BoikoNP@ukr.net;
}

Received February 2021; Accepted March 2021; Published April 2021;

DOI: https://doi.org/10.31407/ijees11.214

\begin{abstract}
The second half of the $20^{\text {th }}$ century was marked by epoch-making discoveries in the field of biochemistry and physiology of crop nutrition. Many of the achievements of the Ukrainian scientists have gone unnoticed by the foreign colleagues during the Soviet era, as most of them have been published in Russian-language periodicals, which have not always been available to them. In this context, the research of Ukrainian researchers, who clarified the essence of the influence of the organic substances, mineral fertilizers, micronutrients and physiologically active substances on the crop growth, development and productivity in different soil and climatic conditions gained importance and worldwide recognition. Their research on the physiological role of manganese in the crop nutrition, the establishment of the biological value of boron, cobalt, lithium, molybdenum, zinc and other microelements are of global priority. For the first time, Ukrainian scientists have compiled cartograms of content of the mobile forms of microelements in different soils of Ukraine. Using the method of the labeled atoms, the researchers have discovered the new patterns of metabolism of carbon, calcium, sulfur, phosphorus and other compounds, which contributed to the effective study of the mechanisms of distribution, supply and transport of nutrients in the crops. This discovery has found wide practical application in agriculture of Ukraine and foreign countries. In particular, the development and application of organo-mineral nutrition of the crops in its rotations, improvement of technologies for growing the cereals and vegetables by establishing industrial production and large-scale application of the organic and mineral fertilizers with micronutrients.
\end{abstract}

Key words: development, improvement, biochemical researches, nutrition physiology, crops, organic substances, mineral fertilizers, microelements, microfertilizers, method of the labeled atoms. 